\title{
RESPONSES OF TWO BARLEY SUBSPECIES TO IN VITRO-INDUCED HEAVY METAL STRESS: SEEDS GERMINATION, SEEDLINGS GROWTH AND CYTOTOXICITY ASSAY
}

\author{
MOHAMED NOURI*, TAOUFIK EL RASAFI, ABDELMAJID HADDIOUI
}

University of Sultan Moulay Slimane, Beni-Mellal, Morocco

\begin{abstract}
NOURI, M. - EL RASAFI, T. - HADDIOUI, A.: Responses of two barley subspecies to in vitro-induced heavy metal stress: seeds germination, seedlings growth and cytotoxicity assay. Agriculture (Polnohospodárstvo), vol. 65,2019 , no. 3 , pp. $107-118$.
\end{abstract}

In this work three heavy metals: cadmium (as $\left.\mathrm{CdSO}_{4}\right)$, cobalt (as $\left.\mathrm{CoCl}_{2}\right)$ and zinc $\left(\right.$ as $\mathrm{ZnSO}_{4}$ ), were used to determine and compare their toxicity towards two subspecies of barley (Hordeum vulgare subsp. vulgare L. and Hordeum vulgare subsp. distichum L.), focusing on seeds germination, seedlings growth, and cytological parameters. The results indicate that the effect of these heavy metals depends on the metal kind, the metal concentrations and the plant subspecies. Generally, in the case of $H$. vulgare, the heavy metal salts understudy did not influence significantly seed germination and seedling growth parameters. However, these metal salts influence significantly these parameters for $H$. distichum. The cytological test showed significant decrease $(p<0.05)$ in the mitotic index among the increase of the heavy metal concentrations when evaluated with the control for $H$. vulgare and $H$. distichum. Consequently, $H$. vulgare seemed to be more tolerant of the increase of the three heavy metals concentrations than $H$. distichum.

Key words: Hordeum vulgare subsp. distichum L.; Hordeum vulgare subsp. vulgare L.; mitotic index; heavy metals

Cereal grains have been a principal human nourishment source for thousands of years. Barley follows the maize, rice, and wheat cereals concerning its global grain production and area under cultivation (Awika 2011). Presently, barley is cultivated over an area of approximately $47 \mathrm{~m}$ ha with a total production of $147 \mathrm{~m}$ tons. More than $60 \%$ of this production arrives from Europe; closely $26 \%$ of it arrives from Americas and Asia together. The major countries producing barley in the world are: Russia, Australia, Germany and France. In Morocco, area under barley is 2,001,473 hectares and production is $2,466,462$ tons (FAOSTAT 2017). Nearly $60 \%$ of barley crop has been utilized as animal feed, around $30 \%$ for beer and malt production, $7 \%$ for production of seed while only $3 \%$ for direct human food with supplementary trans- formation process (couscous, bread, soup) (Baik \& Ullrich 2008).

The Arabic word for barley is shaeir and French orge. The barley varieties grown by farmers in Morocco according to the International Center for Agricultural Research in the Dry Areas (ICARDA) and CIMMYT (Centro Internacional de Mejoramiento de Maïz y Trigo, Spanish, International Maize and Wheat Improvement Center) germplasm since 1984 are: 'Tamellalt' (1984), 'Asni' (1984), 'Tissa' (1984), 'Tiddas' (1988), 'Aglou' (1988), 'Annoceur' (1991), 'Taffa' (1994), 'Massine' (1994), 'Oussama' (1995), 'Igrane' (1996), 'Amira' (1996), 'Amalou' (1997), 'Adrar' (1998), 'Firdaws' (1998) (ICARDA 2005). Only $1 \%$ of the available certified seeds are utilized, nevertheless, and the projections aim to encourage use to $22 \%$ by 2020 (ICARDA 2017).

Mohamed Nouri (*Corresponding author), Laboratory of Biotechnology and Sustainable Development of Natural Resources, Faculty of Polydisciplinary, University of Sultan Moulay Slimane, Beni-Mellal, Morocco. E-mail: mohamednouri35@gmail. com; mohamed.nouri@usms.ma 
Regarding barley's Morocco varieties, a Moroccan origin of some barley varieties has been declared, and some have proposed that there was secondary but independent domestication in Morocco, where barley ancestor variety (H. vulgare subsp. spontaneum) is still present (Martínez-Moreno et al. 2017). Barley is a hardy cereal that can grow in severe environments; it promotes generally stable yields and requires little labor (ICARDA 2017).

Heavy metal pollution of agricultural soils has become a widespread problem in several nations around the world and it resulted in an increase of scientific community interest on the rate of heavy metals uptake by plants and its influences on the quality and security of food (Liang et al. 2018; Nouri \& Haddioui 2016). Morocco is the first producer of phosphate in the world with a production of 32.8 million tons in 2017 (COP 2017). The phosphate industry generates emissions rich in trace elements, such as cadmium, zinc, and chromium, that can pollute environment such as water, air, plants and agricultural soils (Hakkou et al. 2016). A scientific comprehension of $\mathrm{Cd}, \mathrm{Zn}$ and Co toxicity in barley varieties can be very beneficial to choose the adequate variety for every soil type and to alleviate its negative effects on crop performance.

Germination of barley has been examined for decades with the goal to predict and optimize the malting industry. It has become an important model for seed germination study (Daneri-Castro et al. 2016). In Morocco, the most cultivated six-rowed barley variety is $H$. vulgare and two-rowed barley variety is $H$. distichum. The main objective of the current research was to study seed germination parameters, early seedling growth traits and cytological test of two barley subspecies as affected by heavy metals $(\mathrm{Cd}, \mathrm{Co}$ and $\mathrm{Zn})$ stress.

\section{MATERIAL AND METHODS}

\section{Reagents and chemicals}

All reagents and chemicals were purchased from Sigma Aldrich (Steinheim, DE) and were of the ultimate purity.

\section{Seed treatments}

Mature seeds of two subspecies of barley $(H$. vulgare and $H$. distichum $)(2 \mathrm{n}=14)$ obtained from a local commercial supplier in Beni Mellal. Previously, the seeds were separately examined to remove the damaged ones. Seeds rinsed with distilled water, then they were sterilized in $10 \%$ sodium hypochlorite for $10 \mathrm{~min}$, then $70 \%$ alcohol for $60 \mathrm{~s}$, rinsed carefully with sterile distilled water. Subsequently, seeds were germinated in solutions of different metal concentrations.

Barley seeds ( $H$. vulgare and $H$. distichum) were introduced in Petri-dishes (mean $=9 \mathrm{~cm}$ ) with filter paper, to which was added $5 \mathrm{ml}$ of distilled water (control) or 10, 20, 50, 100 and $200 \mathrm{mg} / \mathrm{L} \mathrm{CdSO}_{4}$ or $50,100,200,500$ and $1,000 \mathrm{mg} / \mathrm{L} \mathrm{CoCl}_{2}$ or 100 , 200, 400, 800 and 1,000 mg/L ZnSO 4 solutions. In each glass Petri-dish 20 healthy seeds were sown, in three replicates. Germination was executed at $23 \pm 2{ }^{\circ} \mathrm{C}$, in darkness. The number of germinated seeds was counted every $24 \mathrm{~h}$ for six days. At the end of the test, germination percentage (GP) expressed as (Total seeds germination after day 6 / Total number of planted seeds) $\times 100$ (Ikić et al. 2012). Germination index (GI) was expressed as (\% germination $\times \%$ root length of seeds germination)/100) (Zucconi et al. 1981). Root and shoot lengths of seeds germination were recorded, seeds were considered normally-germinated when their radicle had developed by about $2 \mathrm{~mm}$ in length. Fresh and dry weight were measured after drying seedlings to constant mass at $105^{\circ} \mathrm{C}$ in the oven.

\section{Preparation of mitotic chromosome slides and scoring}

At the end of the germination test, the roottips about $1 \mathrm{~cm}$ length of meristem zones were excised and deposited in aceto-carmine in water bath $\left(60^{\circ} \mathrm{C}\right)$ for about $10-15 \mathrm{~min}$. The slides were examined under an optical microscope at $40 \times$ objectives. The images were captured utilizing a 5 Mega Cmos camera associated to an Olympus CX22LED microscope, with ISCapture Manager Image Software.

A mean of 500 cells was counted from each root to get a total of 3,000 cells per treatment. The mitotic index (MI) was assessed using the formulas:

MI [\%] = the number of dividing cells / the number of total examined cells $(3,000$ per treatment $) \times 100$. 


\section{Statistical analysis}

Percent germination data were transformed by arcsine before to analysis. Data were exposed to the analysis of variance (ANOVA) using a 3 (metal kind) by 5 (metal concentration) by 2 (barley variety) factorial approach with three replications. The results of cytotoxicity are presented as the mean \pm standard deviation (SD) of three replicates, and the statistically significant difference between the treated groups and control was verified applying the oneway ANOVA. The groups were compared utilizing the $L S D$ test at $p<0.05$ level using SPSS software (version 17.0).

\section{RESULTS}

\section{Seed germination}

The results revealed that the evaluated traits of seeds examined were related to the metal types, the concentrations applied and the plant subspecies investigated (Figures 1-3). Cd concentrations significantly affected GP of $H$. distichum $(\mathrm{F}=6.042$, $p=0.005$ ) compared to $H$. vulgare, but $\mathrm{Co}$ and $\mathrm{Zn}$ concentrations not significantly affected GP of any barley variety compared to other (Figure 1A). In contrast, in the control medium the GP of $\mathrm{H}$. distichum was significantly higher for $\mathrm{Cd}$ and $\mathrm{Co}$ and higher for $\mathrm{Zn}$ compared to H. vulgare one (Figure 1A).

The results of GI are summarized in Figure 1B. These results revealed that a significant reduction of GI levels of $H$. distichum compared to $H$. vulgare was recorded, especially, from 10 to $50 \mathrm{mg} \mathrm{Cd} / \mathrm{L}$, $100 \mathrm{mg} \mathrm{Co} / \mathrm{L}$ and $400 \mathrm{mg} \mathrm{Zn/L}$. As well as GP, in the control medium the GI of $H$. distichum was higher compared to $H$. vulgare, but in the other medium is the inverse (Figure 1B). The increase of $\mathrm{Cd}$, Co and $\mathrm{Zn}$ concentrations reduced significantly GI of H. distichum $(\mathrm{F}=16.500, p=0.000)(\mathrm{F}=12.449$, $p=0.000)$ and $(\mathrm{F}=3.863, p=0.026)$ respectively, but not affected significantly GI of $H$. vulgare, compared to the untreated seeds. In contrast, for $H$. vulgare, $\mathrm{Cd}, \mathrm{Co}$ and $\mathrm{Zn}$ induced a slight stimulation at the lower concentrations and an insignificant inhibition at the higher concentrations compared to the control.
Biomass production: fresh and dry weight

Figure 2A shows the influences of $\mathrm{Cd}, \mathrm{Co}$ and $\mathrm{Zn}$ on seedling's fresh weight of two subspecies of barley. A decrease of FW amounts of $H$. distichum compared to $H$. vulgare was noted in all mediums and the effect was significant from 10 to 50 and $200 \mathrm{mg} \mathrm{Cd} / \mathrm{L}$ and 100 and $200 \mathrm{mg} \mathrm{Co} / \mathrm{L}$. An increase in $\mathrm{Cd}$ and $\mathrm{Co}$ concentrations decreased significantly the $\mathrm{FW}$ of $H$. distichum, especially for $\mathrm{Co}(\mathrm{F}=4.743$, $p=0.013)$. Generally, for $H$. vulgare, $\mathrm{Cd}, \mathrm{Co}$ and $\mathrm{Zn}$ did not affect significantly FW compared to the control. In the control medium the FW of $H$. distichum was slightly lower compared to $H$. vulgare.

The results of dry weight are summarized in Figure 2B. As well as FW, a decrease of DW levels of $H$. distichum compared to $H$. vulgare was remarked in all metal mediums and the effect was significant for 20, 50 and $200 \mathrm{mg} \mathrm{Cd} / \mathrm{L}$. Generally, an increase in $\mathrm{Cd}, \mathrm{Co}$ and $\mathrm{Zn}$ concentrations decreased the DW of $H$. distichum especially for $\mathrm{Cd}(\mathrm{F}=3.140$, $p=0.048)$ and no affected significantly the DW of $H$. vulgare, compared to the control. In the control medium, the DW of $H$. distichum was slightly higher compared to $H$. vulgare.

\section{Root and shoot length}

Figure 3A presents the influences of $\mathrm{Cd}, \mathrm{Co}$ and $\mathrm{Zn}$ on seedling's root length of $H$. vulgare and $H$. distichum. An increase in $\mathrm{Cd}$, Co and $\mathrm{Zn}$ concentrations significantly decreased the root length of $H$. distichum compared to $H$. vulgare, the effect was significant for $10-50 \mathrm{mg} \mathrm{Cd} / \mathrm{L}, 50-200 \mathrm{mg} \mathrm{Co} / \mathrm{L}$ and $400 \mathrm{mg} \mathrm{Zn/L}$. Furthermore, the increase in $\mathrm{Cd}$ concentrations significantly diminished the root length of $H$. vulgare $(\mathrm{F}=7.934, p=0.002)$ and of $H$. distichum $(\mathrm{F}=10.906, p=0.000)$. Increase in $\mathrm{Co}$ concentrations significantly reduced the root length of $H$. vulgare $(\mathrm{F}=6.503, p=0.004)$ and of $H$. distichum $(\mathrm{F}=11.684, p=0.000)$. In addition, improve in $\mathrm{Zn}$ concentrations decreased significantly the RL of H. distichum $(\mathrm{F}=5.099, p=0.010)$. In the control medium the RL of $H$. distichum was insignificantly higher compared to $H$. vulgare.

The influence of diverse concentrations of $\mathrm{Cd}$, Co and $\mathrm{Zn}$ on shoot length is shown in Figure 3B. The findings revealed that the enhance in $\mathrm{Cd}$, Co and $\mathrm{Zn}$ concentrations reduced the shoot length of $H$. distichum compared to $H$. vulgare, the 
A
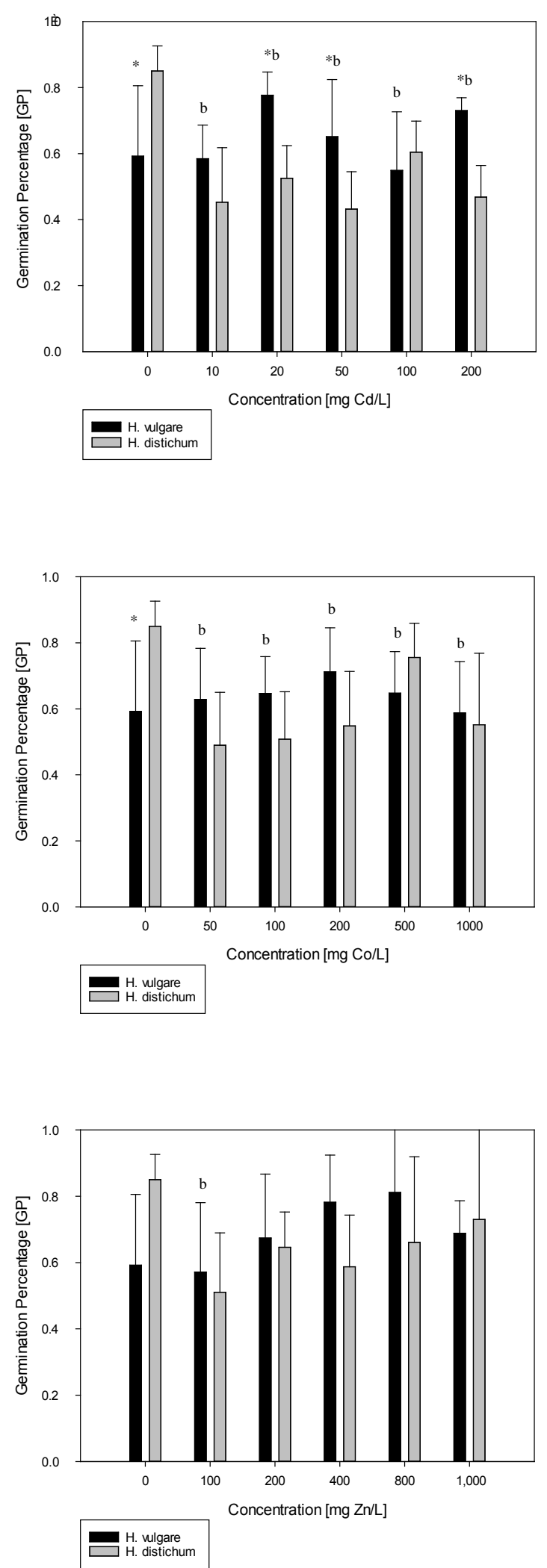

B
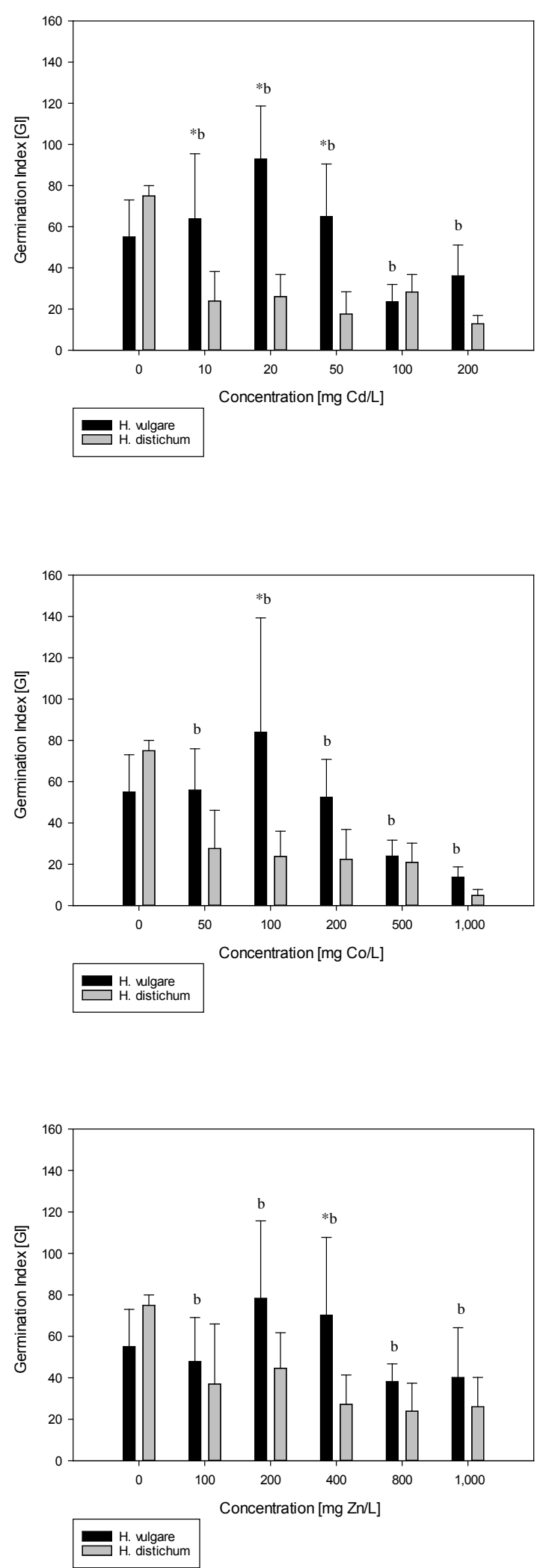

Figure 1. Germination percentage (A) and Germination index (B) of H. vulgare and H. distichum exposed to various concentrations of $\mathrm{Cd}$, Co and $\mathrm{Zn}$. Values are expressed as mean $\pm \mathrm{SD}(\mathrm{n}=3)$. Means marked with $(*)$ are significantly different between subspecies at each concentration at the $5 \%$ level based on $L S D$ test. Significances from the controls are denoted as follows: ${ }^{\mathrm{b}} p<0.05$ for $H$. distichum. 
A
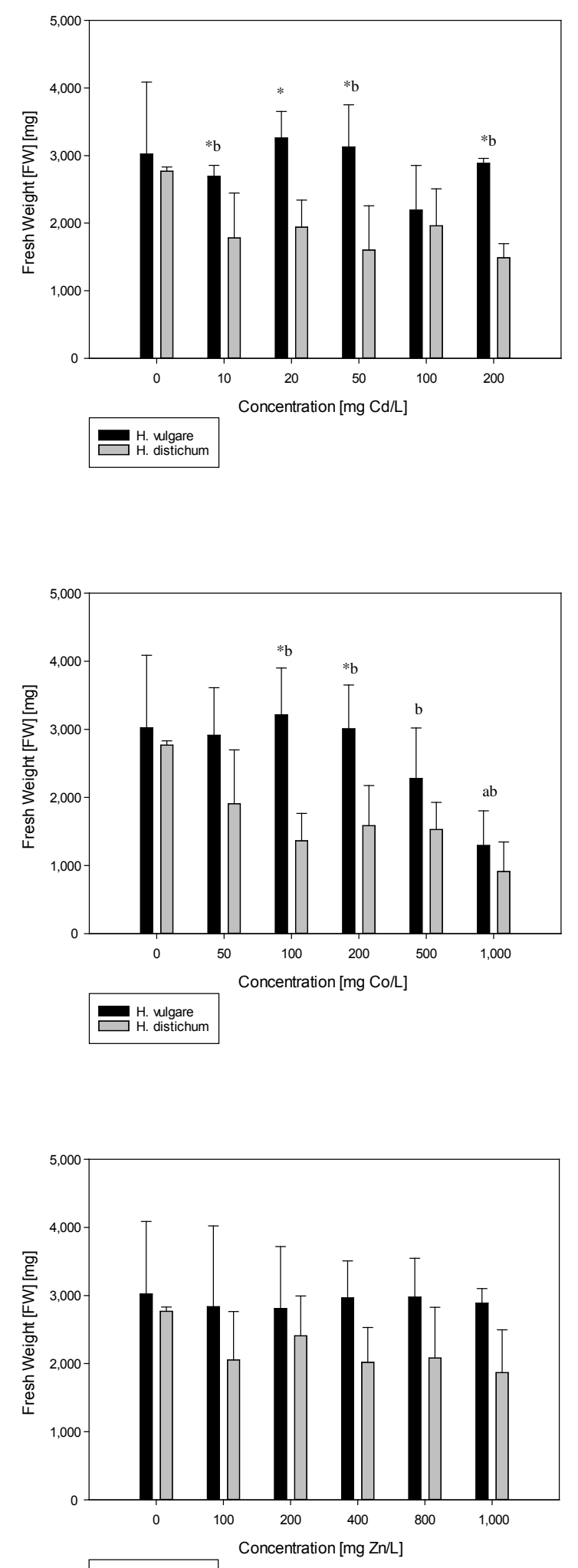

H. vulgare
H. distichum
B
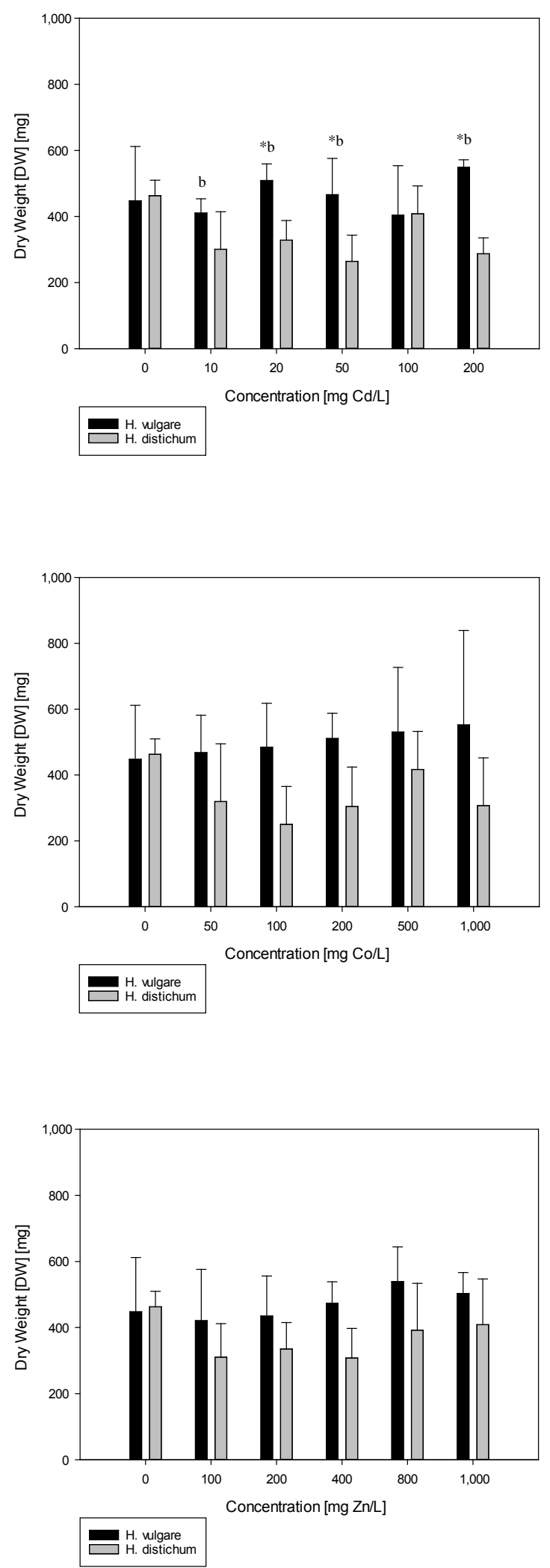

Figure 2. Fresh weight (A) and Dry weight (B) of H. vulgare and H. distichum exposed to various concentrations of Cd, Co and $\mathrm{Zn}$. Values are expressed as mean $\pm \mathrm{SD}(\mathrm{n}=3)$. Means marked with $\left({ }^{*}\right)$ are significantly different between subspecies at each concentration at the $5 \%$ level based on $L S D$ test. Significances from the controls are denoted as follows: ${ }^{a} p<0.05$ for $H$. vulgare and ${ }^{\mathrm{b}} p<0.05$ for $\mathrm{H}$. distichum. 
A
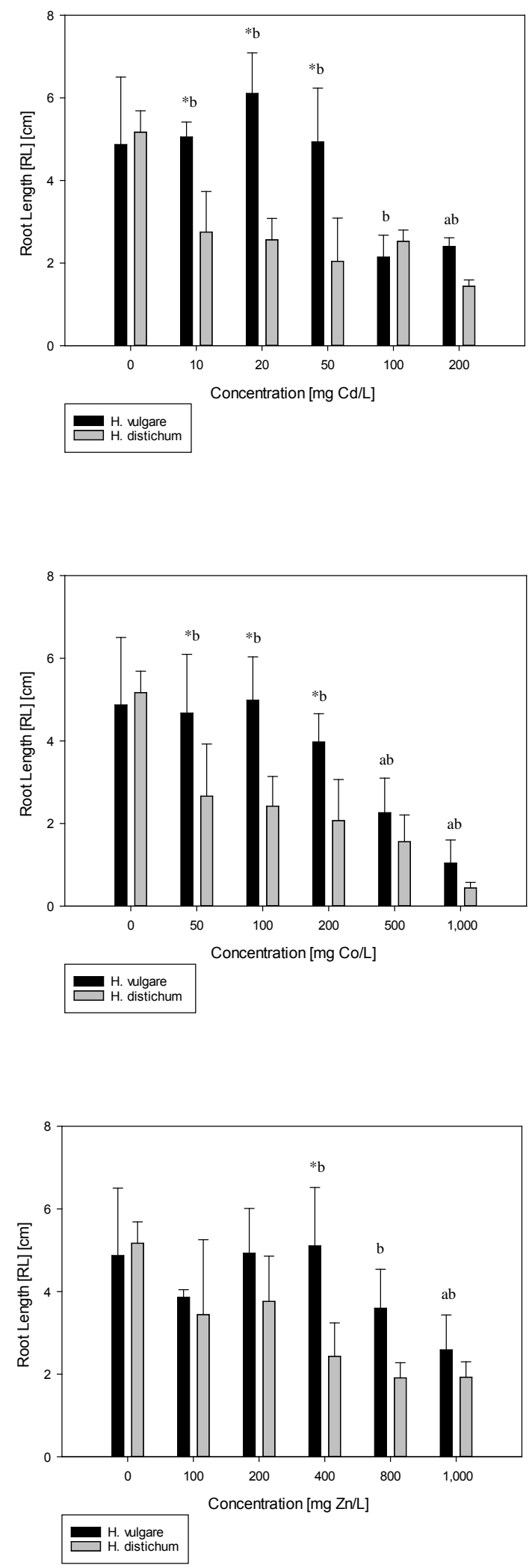

B
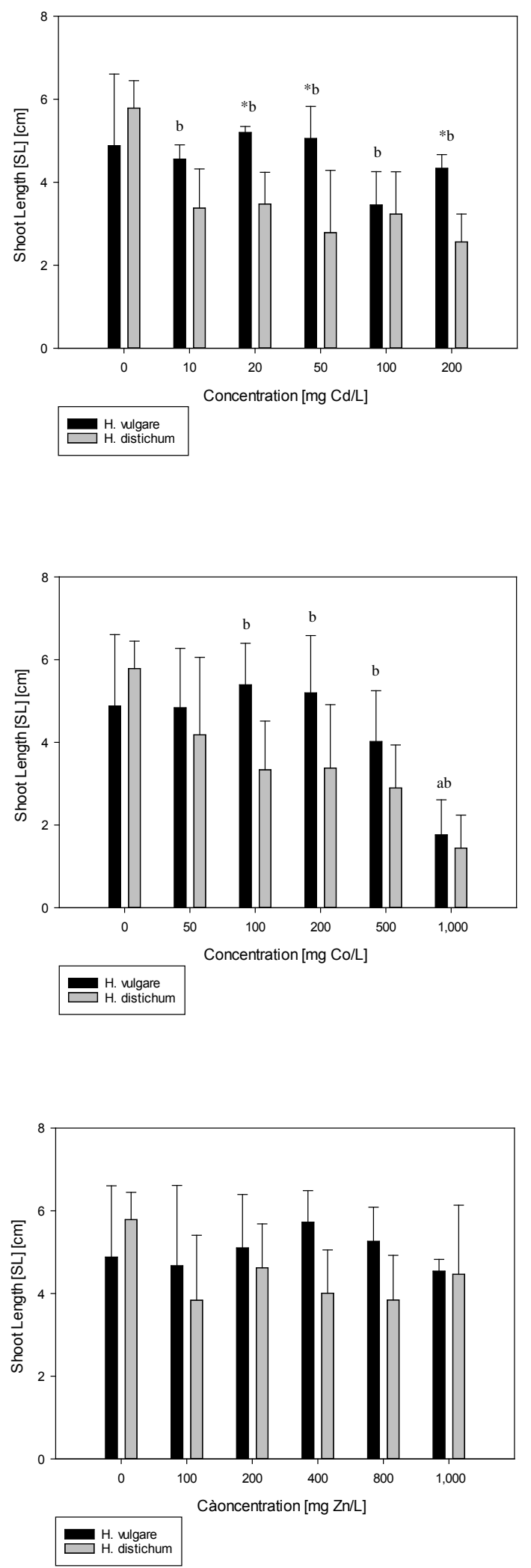

Figure 3. Root length (A) and Shoot length (B) of $H$. vulgare and H. distichum exposed to various concentrations of Cd, Co and $\mathrm{Zn}$. Values are expressed as mean $\pm \mathrm{SD}(\mathrm{n}=3)$. Means marked with $\left({ }^{*}\right)$ are significantly different between subspecies at each concentration at the $5 \%$ level based on $L S D$ test. Significances from the controls are denoted as follows: ${ }^{a} p<0.05$ for $H$. vulgare and ${ }^{\mathrm{b}} p<0.05$ for $H$. distichum. 

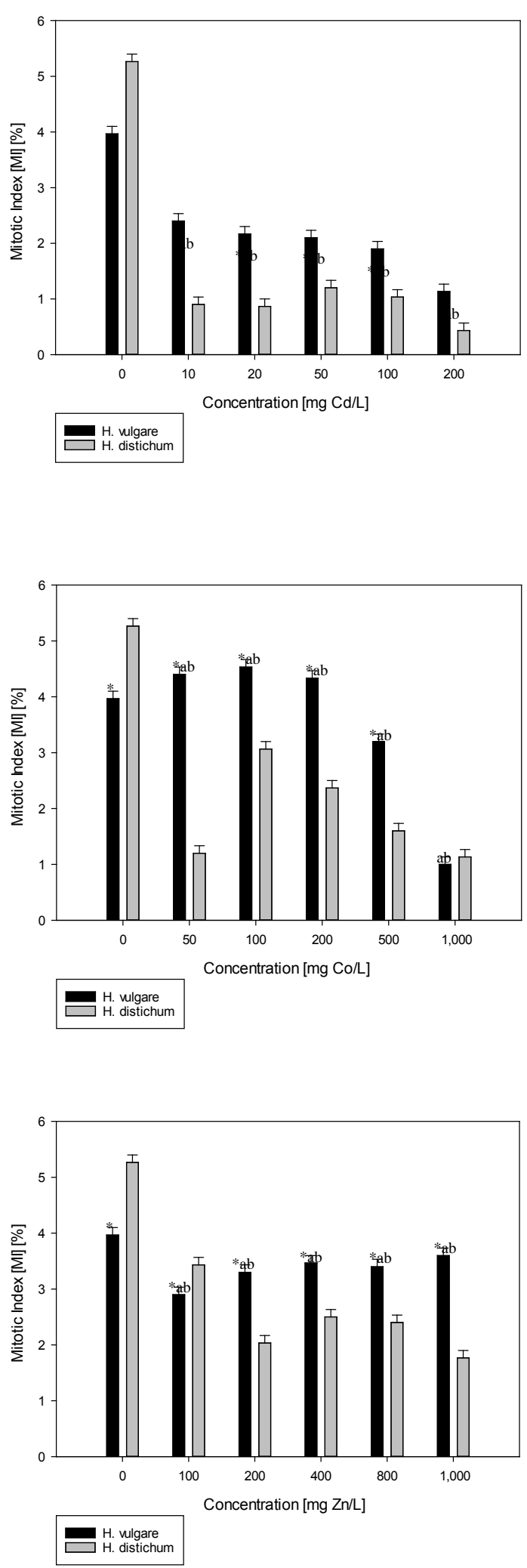

Figure 4. Mitotic index of $H$. vulgare and $H$. distichum exposed to various concentrations of $\mathrm{Cd}, \mathrm{Co}$ and $\mathrm{Zn}$. Values are expressed as mean $\pm \mathrm{SD}(\mathrm{n}=3)$. Means marked with $\left(^{*}\right)$ are significantly different between subspecies at each concentration at the $5 \%$ level based on $L S D$ test. Significances from the controls are denoted as follows: ${ }^{\text {a }} p<0.05$ for $H$. vulgare and ${ }^{\mathrm{b}} p<0.05$ for $H$. distichum. effect was significant for 20,50 and $200 \mathrm{mg} \mathrm{Cd} / \mathrm{L}$. Moreover, the increase in Cd concentrations significantly diminished the shoot length of $H$. distichum $(\mathrm{F}=4.255, p=0.019)$. An increase in Co concentrations significantly reduced the shoot length of $H$. vulgare $(\mathrm{F}=3.219, p=0.045)$ and $H$. distichum $(\mathrm{F}=3.949, p=0.024)$, although for $H$. vulgare only the highest concentration of Co had significant effect. In the control medium the SL of $H$. distichum was insignificantly superior compared to $H$. vulgare.

\section{Mitotic index}

The influences of heavy metals on MI and the rate of mitotic phases are summarized in Figure 4. The results revealed that heavy metals applied in this study significantly reduced, in the general, MI in the treatment groups compared with control for all concentrations, metal kinds and plant varieties. The highest mean MI value was detected in the control root-tips $3.97 \pm 0.09 \%$ for $H$. vulgare and $5.27 \pm 0.11 \%$ for $H$. distichum, and the lowest one $(0.90 \pm 0.03 \%$ for $H$. vulgare and $0.77 \pm 0.01 \%$ for H. distichum) was revealed in treatment with 200 $\mathrm{mg} / \mathrm{L} \mathrm{Cd}$ (Figure 4). Generally, it was shown that when increase metal concentrations; a significant decrease of MI mean values observed relative to control and a significant difference between barley subspecies each other (Table 1). In the $\mathrm{Cd}$ and $\mathrm{Zn}$ medium, the MI of $H$. vulgare was significantly higher compared to $H$. distichum. In contrast, in the Co medium, MI of $H$. vulgare was significantly higher compared to $H$. distichum only in low concentrations.

In the heavy metal contaminated medium $H$. vulgare showed greater GP, GI, FW and DW as well as the longest RL and SL. However, in uncontaminated medium (control) H. distichum showed greater germination traits as well as the longest early seedling growth parameters.

Heavy metal types significantly affected $(P<0.05)$ SL, RL, and FW, besides affected $(P<0.01) \mathrm{MI}$ (Table 1). Heavy metal concentrations significantly affected $(P<0.01)$ GI, FW, and MI, moreover, significantly affected $(P<0.05)$ GP, SL, and RL. Barley varieties significantly affected $(P<0.01) \mathrm{GI}, \mathrm{SL}$, RL, FW, DW, and MI. There was also a significant interaction between concentration and barley variety interaction was observed for GP, GI, SL, and RL 
(Table 1). However, the interaction between heavy metal kind and metal concentration, between heavy metal kind and plant variety and between heavy metal kind and metal concentration and plant variety did not affect GP, GI, SL, RL, FW, and DW, conversely, they affected $(P<0.01)$ MI.

\section{DISCUSSION}

Data of this work deliver advantageous information about the comparison between $H$. vulgare and $H$. distichum seed germination and early seedling growth in presence of heavy metallic stress. Generally, $H$. vulgare was less affected in its seed germination and early seedling growth. It should be noted however that the primary objective of this study was to compare the stimulation or inhibition of the $H$. vulgare and $H$. distichum subspecies in presence of heavy metals (Cd, Co and $\mathrm{Zn}$ ), by examining germination as well as early seedling growth parameters and cytological test.

Our findings are largely coherent with preceding studies, concerning $H$. distichum, which have shown that heavy metal stress affects significantly germination parameters (Chen et al. 2008; He et al. 2017; Tamás et al. 2017).
The paper casts some light on the influences of heavy metal kinds and heavy metal concentrations on $H$. vulgare and $H$. distichum subspecies. While the germination method is well known, prior researches indicated that more study is necessary to determine the value of heavy metal stress in diverse crop varieties (Seneviratne et al. 2019). Consequently, seed germination is frequently utilized to assess contamination consequences on plants (Miralles et al. 2012). However, our results clearly revealed that the use of Cd significantly inhibited $H$. distichum seeds germination. Conversely, the application of $\mathrm{Cd}$ did not influence significantly this parameter for $H$. vulgare, even at $200 \mathrm{mg} / \mathrm{L}$. Regarding the application of $\mathrm{Co}$ and $\mathrm{Zn}$, in general, no significant differences were detected between $H$. vulgare and $H$. distichum seeds germination. Insignificant biostimulation was observed in $H$. vulgare seeds subjected to $\mathrm{Cd}, \mathrm{Co}$ and $\mathrm{Zn}$. In accordance with our results, a small biostimulation of germination by low $\mathrm{Cd}$ concentrations was reported (Lefèvre et al. 2009). These maybe possible alerts since the biostimulation could be the early cause of hormesis (Baderna et al. 2015) or attributed to the stimulation of cell activities through improved ROS signaling (Gapper \& Dolan 2006).

To date, several nations used the germination index (GI) to evaluate the quality of amendment as the

$\mathrm{T}$ a

Analysis of variance of evaluated traits

\begin{tabular}{|c|c|c|c|c|c|c|c|}
\hline \multirow{2}{*}{ Source of Variance } & \multicolumn{7}{|c|}{ Mean Squares } \\
\hline & GP & GI & SL & RL & FW & DW & MI \\
\hline Heavy metals (HM) & 0.051 & 681.57 & $6.70^{+}$ & $3.88^{+}$ & $1,522,198.14^{+}$ & $3,630.39$ & $9.753^{++}$ \\
\hline Concentrations (C) & $0.066^{+}$ & $5,118.04^{++}$ & $9.41^{+}$ & $27.06^{+}$ & $2,035,133.96^{++}$ & $22,960.78$ & $15.571^{++}$ \\
\hline Plant varieties $(\mathrm{PV})$ & 0.053 & $10,738.64^{++}$ & $18.61^{++}$ & $43.35^{++}$ & $2.03 \mathrm{E}^{++}$ & $430,752.47^{++}$ & $15.565^{++}$ \\
\hline $\mathrm{HM} \times \mathrm{C}$ & 0.014 & 119.21 & 2.26 & 0.56 & $455,405.09$ & $3,202.40$ & $2.811^{++}$ \\
\hline $\mathrm{HM} \times \mathrm{PV}$ & 0.015 & 214.50 & 0.44 & 0.46 & $153,220.16$ & $6,937.24$ & $7.823^{++}$ \\
\hline $\mathrm{C} \times \mathrm{PV}$ & $0.120^{++}$ & $3,101.90^{++}$ & $4.14^{+}$ & $5.42^{++}$ & $657,371.91$ & $30,158.07$ & 0.619 \\
\hline $\mathrm{HM} \times \mathrm{C} \times \mathrm{PV}$ & 0.015 & 180.77 & 0.54 & 1.06 & $279,494.30$ & $4,741.44$ & $2.492^{++}$ \\
\hline Error & 0.025 & 403.09 & 1.35 & 0.91 & $401,387.08$ & $14,758.84$ & 0.018 \\
\hline
\end{tabular}

GP - germination percentage; GI - germination index; SL - shoot length; RL - root length; FW - fresh weight; DW - dry weight; $\mathrm{MI}$ - mitotic index

${ }^{+}$Significant at the 0.05 level of probability; ${ }^{++}$Significant at the 0.01 level of probability 
result of the combination of plant-germination and root elongation (Da Ros et al. 2018). GI was preferred for its sensitivity, short time requirement and simplicity, being the phase of germination intensely influenced by environmental conditions (Wang 1991). The findings of this study indicated that the increase of $\mathrm{Cd}$, Co and $\mathrm{Zn}$ concentrations reduced significantly GI of $H$. distichum compared to $H$. vulgare. Furthermore, the increase of these metal concentrations reduced significantly germination traits of $H$. distichum, but not affected those of $H$. vulgare, evaluated to the control seeds. In agreement with these data, Baderna et al. (2015) reported that $\mathrm{Cd}$ and $\mathrm{Zn}$ salts had no toxicity on cucumber, sorghum, and cress. Moreover, numerous researchers also reported the absence of sensitiveness of seed germination on Cd (Kopyra \& Gwóźdź 2003; Ozdener \& Kutbay 2009; Street et al. 2007) and zinc (Lefèvre et al. 2009; Madzhugina et al. 2008; Ozdener \& Kutbay 2009; Street et al. 2007). In another study of us, the $\mathrm{Zn}$ and $\mathrm{Co}$ had almost no significant effect on germination traits of Lepidium sativum L. (Data not shown).

Certainly, the possible risk of heavy metals and other pollutants in the damage of seed germination is extremely reliant on their ability to attain embryogenic tissues, which are covered by coats, structures with permeability differential to diverse elements and selectivity of embryos versus metals (Akinci \& Akinci 2010; Seregin \& Kozhevnikova 2005). In addition, seed germination dependent on the metabolic trails functioning inside the grain through the full germination process, which are strongly reliant on genes expression (Daneri-Castro et al. 2016). Moreover, Daneri-Castro et al. (2016) reported that gene expression has also been correlated with the imbibition of the grain.

Simultaneously with the assessment of germination, it is also usual to examine parameters allied to seedling growth, because seedling's growth levels are essential bioassay endpoints to assess the harmfulness of a substance (Adrees et al. 2015). Regarding the seedling growth parameters (RL, SL, FW and DW) for this study we revealed that an increase in $\mathrm{Cd}$, Co and $\mathrm{Zn}$ concentrations decreased these parameters for $H$. distichum compared to $H$. vulgare. Analyzing these plant varieties individually, the findings showed that increasing heavy met- al concentrations decrease the seedling growth parameters compared to the control for $H$. distichum. In contrast, for $H$. vulgare, generally, improving heavy metal concentrations did not affect significantly these parameters and sometimes we observed a slight stimulation. In accordance with our results, Ebbs and Kochian (1998) reported that $H$. vulgare had a phytoremediation potential for $\mathrm{Zn}$ and tolerated the high $\mathrm{Cu}, \mathrm{Cd}$, and $\mathrm{Zn}$ concentrations.

According to Ozdener and Kutbay (2009), 810 $\mu \mathrm{mol} / \mathrm{L} \mathrm{Cd}$ decreased RL, but did not influence the germination rate of Eruca sativa. Nevertheless, SL was decreased for this plant seeds treated with $650 \mu \mathrm{mol} / \mathrm{L}$, and no germination happened at 240 $\mu \mathrm{mol} / \mathrm{L} \mathrm{Cd}$. In addition, low Cd levels slightly stimulated seedlings growth of Dorycnium pentaphyllum (Lefèvre et al. 2009).

Habitually, the model dose-response founded rigorously on monotonic functions. These models can explain the $H$. distichum variations. Conversely, these functions cannot be utilized to explain the relations gotten in our study for $H$. vulgare. These findings have revealed that the models counting hormesis explained the $H$. vulgare data significantly better than the dose-response one. Several authors reported the hormesis phenomenon for plants developing on the presence of metals (Baderna et al. 2015; Calabrese \& Blain 2009; Hagner et al. 2018; Wang et al. 2010) or other substances (Geras'kin et al. 2017). Moreover, Martínez-Moreno et al. (2017) reported that the barley varieties contain genes for tolerance and resistance to abiotic and biotic stresses.

In accordance with Baderna et al. (2015), our findings might assume that the manners in which the heavy metals affect seed germination and seedling growth are variety-specific and compound-specific. The influences of these contaminants differ with crop species, specific heavy metal and concentration (Nagajyoti et al. 2010). Common ways of action are interference with oxidative stress, senescence and metabolic functions (Seneviratne et al. 2019; Shahzad et al. 2018; Singh et al. 2018).

Variations in mitotic activities and its inhibition are usually utilized as an essential indicator in environmental monitoring and for the assessment the toxicity of substances (Fernandes et al. 2007). MI decreases in the presence of abiotic stress (Artico 
et al. 2018; Datta et al. 2018) such as that produced by $\mathrm{Cd}, \mathrm{Co}$ and $\mathrm{Zn}$. In the current work, the MI evaluated in root-tips from seeds treated with $\mathrm{Cd}, \mathrm{Co}$ and $\mathrm{Zn}$ salt was inferior to the MI values detected in control for the two barley varieties. Moreover, the lowest mean MI values were observed in the treatments: $200 \mathrm{mg} / \mathrm{L} \mathrm{Cd}$. On the other hand, the highest MI mean values were detected in treatments with $100 \mathrm{mg} / \mathrm{L}$ Co (Table 3).

The results of mitotic activity showed that an increase in $\mathrm{Cd}$, Co and $\mathrm{Zn}$ levels decreased significantly the MI for $H$. distichum compared to $H$. vulgare MI can consistently classify the cytotoxic effects of an element. A 50\% diminution in MI when evaluated to control is a limit: $50 \%$ diminution produces a sub-lethal effect and $<22 \%$ provokes a lethal effect (Mesi \& Kopliku 2013). Accordingly to Mesi \& Kopliku (2013), 100 and $200 \mathrm{mg} \mathrm{Cd/L,} \mathrm{50,}$ 500 and $1,000 \mathrm{mg} \mathrm{Co} / \mathrm{L}$ and $1,000 \mathrm{mg} \mathrm{Zn} / \mathrm{L}$ caused sub-lethal effect for $\mathrm{H}$. vulgare. However, for $H$. distichum $50 \mathrm{mg} \mathrm{Cd} / \mathrm{L}$ caused sub-lethal effect, 10, 20 and $100 \mathrm{mg} \mathrm{Cd} / \mathrm{L}$ and $1,000 \mathrm{mg} \mathrm{Co} / \mathrm{L}$ caused lethal effect. Türkoğlu (2008) reported that the reduction in mitotic activity can be produced by the blockage of the $\mathrm{G} 2$ phase of the cell cycle or by the inhibition of DNA synthesis, stopping the cell from dividing.

Macroscopic alterations of root development in barley, produced by contaminants characterize phenotype expression of the modifications in root genetic material of tip cells. These genetic modifications are in relation to anomalies of chromosomes and mitosis aberrations of cells. The root tip development is allied to the meristem cell multiplying which is characterized by an index of mitosis (Birdsall \& MacLeod 1990). As radicle tips are extremely sensitive to environmental impacts contaminants produce the reduction of the index mitosis (Fiskesjö 1985) among anomalies of chromosomes whose amount is clearly proportional to contaminant dose and the exposure period to it (Al-Sabti \& Kurelec 1985).

\section{CONCLUSIONS}

The phytotoxicity of heavy metal salts for two barley subspecies was evaluated considering the seed germination seedlings growth and cytological assay.
Results revealed that the effect of increasing heavy metal concentrations on seed germination traits and seedling growth parameters was significant for $H$. distichum and insignificant for $H$. vulgare. The superior MI value detected for $H$. vulgare compared to $H$. distichum is characteristics that place this plant in a position of tolerance. Nevertheless, $H$. distichum presented greater sensitivity to the toxic influences of the tested heavy metals. In the light of our initial findings, further research is needed to interpret the mechanisms of $H$. vulgare tolerance, $H$. distichum sensitiveness and determine more protecting guidelines for plants for metals in soils.

Acknowledgements. The author wishes to thank El Mouden Jaouad, El Ouardi Mohamed, Amadar Imad, El Fakkak Hassan, Edahri Soufiane and Htoura Youness for their competent technical assistance.

\section{REFERENCES}

ADREES, M. - ALI, S. - RIZWAN, M. - IBRAHIM, M. - ABBAS, F. - FARID, M. - ZIA-UR-REHMAN, M. IRSHAD, M.K. - BHARWANA, S.A. 2015. The effect of excess copper on growth and physiology of important food crops: a review. In Environmental Science and Pollution Research, vol. 22, pp. 8148-8162.

AKINCI, I.E. - AKINCI, S. 2010. Effect of chromium toxicity on germination and early seedling growth in melon $\mathrm{Cu}-$ cumis melo L.). In African Journal of Biotechnology, vol. 9, pp. 4589-4594.

AL-SABTI, K. - KURELEC, B. 1985. Chromosomal aberrations in onion (Allium cepa) induced by water chlorination by-products. In Bulletin of Environmental Contamination and Toxicology, vol. 34, pp. 80-88.

ARTICO,L.L.-KOMMLING, G.-MIGITA,N.A.-MENEZES, A.P.S. 2018. Toxicological effects of surface water exposed to coal contamination on the test system Allium cepa. In Water, Air, \& Soil Pollution, vol. 229, pp. 248.

AWIKA, J.M. 2011. Major cereal grains production and use around the world. In Advances in cereal science: implications to food processing and health promotion, Chapter 1, pp: 1-13, Washington, DC: ACS Symposium Series; American Chemical Society.

BADERNA, D. - LOMAZZI, E. - POGLIAGHI, A. - CIACCIA, G. - LODI, M. - BENFENATI, E. 2015. Acute phytotoxicity of seven metals alone and in mixture: Are Italian soil threshold concentrations suitable for plant protection? In Environmental Research, vol. 140, pp. 102-111.

BAIK, B.-K. - ULLRICH, S.E. 2008. Barley for food: Characteristics, improvement, and renewed interest. In Journal of Cereal Science, vol. 48, pp. 233-242.

BIRDSALL, M. - MACLEOD, R.D. 1990. Early growth of the root system in Allium cepa. In Canadian Journal of Botany, vol. 68 , pp. $747-753$.

CALABRESE, E.J. - BLAIN, R.B. 2009. Hormesis and plant biology. In Environmental Pollution, vol. 157, pp. 42-48.

CHEN, F. - WANG, F. - ZHANG, G. - WU, F. 2008. Identi- 
fication of barley varieties tolerant to cadmium toxicity. In Biological Trace Element Research, vol. 121, pp. 171-179.

COP (Cherifian Office of Phosphates) 2017. Annuel Report. Avaiable at: 2017 (https://www.ocpgroup.ma/sites/default/ files/2018-11/RA\%20OCP\%202017\%20VF.pdf

DANERI-CASTRO, S.N. - SVENSSON, B. - ROBERTS, T.H. 2016. Barley germination: spatio-temporal considerations for designing and interpreting 'omics' experiments. In Journal of Cereal Science, vol. 70, pp. 29-37.

DATTA, S. - SINGH, J. - SINGH, J. - SINGH, S. - SINGH, S. 2018. Assessment of genotoxic effects of pesticide and vermicompost treated soil with Allium cepa test. In Sustainable Environment Research, vol. 28, pp. 171-178.

EBBS, S.D. - KOCHIAN, L.V. 1998. Phytoextraction of zinc by oat (Avena sativa), barley (Hordeum vulgare), and indian mustard (Brassica juncea). In Environmental Science \& Technology, vol. 32, pp. 802-806.

FAOSTAT, 2017. Food and Agriculture Organization of the United Nations, http://www.fao.org/faostat/en/\#data/QC/ visualize

FERNANDES, T.C.C. - MAZZEO, D.E.C. - MARIN-MORALES, M.A. 2007. Mechanism of micronuclei formation in polyploidizated cells of Allium cepa exposed to trifluralin herbicide. In Pesticide Biochemistry and Physiology, vol. 88 , pp. $252-259$.

FISKESJÖ, G. 1985. Allium test on river water from Braån and Saxån before and after closure of a chemical factory. In $\mathrm{Am}$ bio, vol. 14, pp. 99-103.

GAPPER, C. - DOLAN, L. 2006. Control of plant development by reactive oxygen species. In Plant Physiology, vol. 141, pp. $341-345$.

GERAS'KIN, S. - CHURYUKIN, R. - VOLKOVA, P. 2017. Radiation exposure of barley seeds can modify the early stages of plants' development. In Journal of Environmental Radioactivity, vol. 177, pp. 71-83.

HAGNER, M. - ROMANTSCHUK, M. - PENTTINEN, O.P. - EGFORS, A. - MARCHAND, C. - AUGUSTSSON, A. 2018. Assessing toxicity of metal contaminated soil from glassworks sites with a battery of biotests. In Science of the Total Environment, vol. 613-614, pp. 30-38.

HAKKOU, R. - BENZAAZOUA, M. - BUSSIÈRE, B. 2016 Valorization of phosphate waste rocks and sludge from the Moroccan phosphate mines: challenges and perspectives. In Procedia Engineering, vol. 138, pp. 110-118.

HE, S. - YANG, X. - HE, Z. - BALIGAR, V.C. 2017. Morphological and physiological responses of plants to cadmium toxicity: a review. In Pedosphere, vol. 27, pp. 421-438.

ICARDA (International Center for Agricultural Research in \& the Dry Areas). 2005. Morocco and ICARDA: Collaboration since 1977, second (Ed ICARDA). Aleppo, Syria.

ICARDA (International Center for Agricultural Research in the Dry Areas. 2017. ANNUAL REPORT 2016 Enhancing Resilience: Helping Dryland Communities to Thrive. Beirut, Lebanon: ICARDA

IKIĆ, I. - MARIČEVIĆ, M. - TOMASOVIĆ, S. - GUNJAČA J. - ŠATOVIĆ, Z. - ŠARČEVIĆ, H. 2012. The effect of germination temperature on seed dormancy in Croatian-grown winter wheats. In Euphytica, vol. 188, pp. 25-34.

KOPYRA, M. - GWÓŹDŹ, E.A. 2003. Nitric oxide stimulates seed germination and counteracts the inhibitory effect of heavy metals and salinity on root growth of Lupinus luteus. In Plant Physiology and Biochemistry, vol. 41, pp. $1011-1017$.

LEFĖVRE, I. - MARCHAL, G. - CORRÉAL, E. - ZANUZZI, A. - LUTTS, S. 2009. Variation in response to heavy metals during vegetative growth in Dorycnium pentaphyllum Scop. In Plant Growth Regulation, vol. 59, pp. 1-11.
LIANG, C. - XIAO, H. - HU, Z - ZHANG, X. - HU, J. 2018. Uptake, transportation, and accumulation of C60 fullerene and heavy metal ions $(\mathrm{Cd}, \mathrm{Cu}$, and $\mathrm{Pb})$ in rice plants grown in an agricultural soil. In Environmental Pollution, vol. 235, pp. $330-338$.

MADZHUGINA, Y.G. - KUZNETSOV, V.V. - SHEVYAKOVA, N.I. 2008. Plants inhabiting polygons for megapolis waste as promising species for phytoremediation. In Russian Journal of Plant Physiology, vol. 55, pp. 410-419.

MARTÍNEZ-MORENO, F. - SOLIS, I. - IGARTUA, E. 2017. Barley Types and varieties in Spain: a historical overview. In Ciencia e Investigación Agraria, vol. 44, pp. 1-12.

MESI, A. - KOPLIKU, D. 2013. Cytotoxic and genotoxic potency screening of two pesticides on Allium cepa L. In Procedia Technology, vol. 8, pp. 19-26.

MIRALLES, P. - CHURCH, T.L. - HARRIS, A.T. 2012. Toxicity, uptake, and translocation of engineered nanomaterials in vascular plants. In Environmental Science \& Technology, vol. 46, pp. 9224-9239.

NAGAJYOTI, P.C. - LEE, K.D. - SREEKANTH, T.V.M. 2010. Heavy metals, occurrence and toxicity for plants: A review. In Environmental Chemistry Letters, vol. 8, pp. 199-216.

NOURI, M. - HADDIOUI, A. 2016. Human and animal health risk assessment of metal contamination in soil and plants from Ait Ammar abandoned iron mine, Morocco. In Environmental Monitoring and Assessment, vol. 188, pp. 6.

OZDENER, Y. - KUTBAY, H.G. 2009. Toxicity of copper, cadmium, nickel, lead and zinc on seed germination and seedling growth in Eruca sativa. In Fresenius Environmental Bulletin, vol. 18, pp. 26-31.

DA ROS, C. - LIBRALATO, G. - GHIRARDINI, A.V. - RADAELLI, M. - CAVINATO, C. 2018. Assessing the potential phytotoxicity of digestate from winery wastes. In Ecotoxicology and Environmental Safety, vol. 150, pp. 26-33.

SENEVIRATNE, M. - RAJAKARUNA, N. - RIZWAN, M. MADAWALA, H.M.S.P. - OK, Y.S. - VITHANAGE, M. 2019. Heavy metal-induced oxidative stress on seed germination and seedling development: a critical review. In Environmental Geochemistry and Health, vol. 41, pp. 18131831. https://doi.org/10.1007/s10653-017-0005-8

SEREGIN, I.V. - KOZHEVNIKOVA, A.D. 2005. Distribution of cadmium, lead, nickel, and strontium in imbibing maize caryopses. In Russian Journal of Plant Physiology, vol. 52, pp. $565-569$.

SHAHZAD, B. - TANVEER, M. - CHE, Z. - REHMAN, A. - CHEEMA, S.A. - SHARMA, A. - SONG, H. - REHMAN, S. - ZHAORONG, D. 2018. Role of 24-epibrassinolide (EBL) in mediating heavy metal and pesticide induced oxidative stress in plants: A review. In Ecotoxicology and Environmental Safety, vol. 147, pp. 935-944.

SINGH, R. - UPADHYAY, A.K. - SINGH, D.P. 2018. Regulation of oxidative stress and mineral nutrient status by selenium in arsenic treated crop plant Oryza sativa. In Ecotoxicology and Environmental Safety, vol. 148, pp. 105-113.

STREET, R.A. - KULKARNI, M.G. - STIRK, W.A. - SOUTHWAY, C. - VAN STADEN, J. 2007. Toxicity of metal elements on germination and seedling growth of widely used medicinal plants belonging to Hyacinthaceae. In Bulletin of Environmental Contamination and Toxicology, vol. 79, pp. $371-376$.

TAMÁS, L. - MISTRÍK, I. - ZELINOVÁ, V. 2017. Heavy metal-induced reactive oxygen species and cell death in barley root tip. In Environmental and Experimental Botany, vol. 140 , pp. 34-40.

TÜRKOĞLU, Ş. 2008. Evaluation of genotoxic effects of sodium propionate, calcium propionate and potassium propionate on the root meristem cells of Allium cepa. In Food and 
Chemical Toxicology, vol. 46, pp. 2035-2041.

WANG, W. 1991. Literature review on higher plants for toxicity testing. In Water, Air, and Soil Pollution, vol. 59, pp. $381-400$.

WANG, C.R. - TIAN, Y. - WANG, X.R. - YU, H.X. - LU, X.W. - WANG, C. - WANG, H. 2010. Hormesis effects and implicative application in assessment of lead-contaminated soils in roots of Vicia faba seedlings. In Chemosphere, vol. 80, pp. $965-971$.
ZUCCONI, F. - PERA, A. - FORTE, M. - BERTOLDI, M. 1981. Evaluating toxicity of immature compost. In Biocycle, vol. 22, pp. 54-57.

Received: May 29, 2019 Accepted: September 12, 2019 